\title{
Tough $\mathrm{TiB}_{2}$-Based Ceramic Composites Using Metallic Glass Powder as the Sintering Aid**
}

\author{
By Chao Yang, ${ }^{*}$ Yuanpeng Yao, Yong Huan, Zhiqiang Fu, Fei Chen and Enrique J. Lavernia*
}

In this work, the authors report on the formation of toughened $\mathrm{TiB}_{2}$-based ceramic composites using $\mathrm{Ti}_{60.8} \mathrm{Al}_{25} \mathrm{Nb}_{10} \mathrm{~V}_{3} \mathrm{Mo}_{1} \mathrm{~B}_{0.2}$ (at\%) metallic glass powder as sintering aid fabricated by spark plasma sintering. The $\mathrm{TiB}_{2}$ ceramic powder blended with 5 wt\% metallic glass sintering aid exhibits an interesting sigmoidal shrinkage behavior which is argued to be attributable to the viscous flow of metallic glass powder. The fabricated $\mathrm{TiB}_{2}$-based ceramic composites have high relative density of $99.1 \%$ and high fracture toughness of $9.9 \mathrm{Mpa} \mathrm{m}^{1 / 2}$. The fracture toughness values obtained in this study are related to the mechanical response of the TiAl phase, which transformed from the metallic glass sintering aid. The results obtained herein provide a novel pathway for the fabrication of high-performance ceramic composites.

\section{Introduction}

The titanium diboride $\left(\mathrm{TiB}_{2}\right)$ ceramic possesses a series of notable physical, mechanical, and chemical properties, such as high melting point, high hardness, high strength-to-weight

[*] Dr. C. Yang, Dr. Y. P. Yao, Dr. Z. Q. Fu

National Engineering Research Center of Near-Net-Shape Forming for Metallic Materials, South China University of Technology, Guangzhou 510640, China

E-mail: cyang@scut.edu.cn

Dr. E. J. Lavernia, Dr. Z. Q. Fu

Department of Chemical Engineering and Materials Science, University of California, Irvine, California, 92697, USA

E-mail: lavernia@uci.edu

Dr. F. Chen

State Key Lab of Advanced Technology for Materials Synthesis and Processing, Wuhan University of Technology, Wuhan 430070, China

Dr. Y. Huan

State Key Laboratory of Nonlinear Mechanics, Institute of Mechanics, Chinese Academy of Sciences, Beijing 100190, China

[**] This work was supported by the National Natural Science Foundation of China (Nos. 51574128 and 11372323), the Guangdong Natural Science Foundation for Research Team (No. 2015A030312003), the Guangdong Special Funds for Public Welfare Research and Capacity Building (No. 2014A010105020), and the "111" project (No. B13035). We declare that they have no conflict of interest. This article does not contain any studies with human participants or animals performed by any of the authors. Informed consent was obtained from all individual participants included in the study. ratio, and good corrosion and wear resistance. These excellent properties render it an outstanding engineering material for various applications, including high-temperature structural components, wear-resistant parts, cutting tools, and lightweight ballistic protection armor materials. ${ }^{[1-3]}$ In such applications, both relative density and fracture toughness represent two parameters that are frequently used to evaluate the effectiveness and service life of $\mathrm{TiB}_{2}$ components.

It is well established that the densification of monolithic $\mathrm{TiB}_{2}$ requires high sintering temperatures, sometimes as high as $2200^{\circ} \mathrm{C}$, and long sintering times due to its strong ionic and covalent bonding, low self-diffusion coefficient and the presence of an oxygen rich surface layer (primarily $\mathrm{TiO}_{2}$ and $\left.\mathrm{B}_{2} \mathrm{O}_{3}\right){ }^{[4,5]}$ These characteristics of $\mathrm{TiB}_{2}$ make it challenging to achieve near full density, even when using pressure-assisted sintering methods such as hot pressing and hot isostatic pressing. ${ }^{[6]}$ This has limited the use of monolithic $\mathrm{TiB}_{2}$ in engineering applications. ${ }^{[7,8]}$ Compared with conventional sintering methods, spark plasma sintering (SPS) is a comparatively novel sintering technique allows the compaction of ceramics to be sintered with higher density at lower temperature with decreased sintering times. ${ }^{[9]}$ During the SPS sintering process, spark discharge, joule heating, and plastic deformation effects all contribute to densification behavior. $^{[10]}$ In particular, the presence of a spark discharge has been argued to effectively disrupt any surface oxide films that may be present on the ceramic particles. ${ }^{[6]}$ As a result, grain growth can be prevented due to the accelerated densification kinetics. Hence, the SPS provides notable benefits as an effective method to fabricate $\mathrm{TiB}_{2}$ ceramics as well as its composites. 
To fabricate bulk $\mathrm{TiB}_{2}$-based ceramic composites with high relative density and fracture toughness, a sintering aid is generally required. Inspection of the published literature shows that $\mathrm{CrB}_{2}$ ceramics, ${ }^{[11]} \mathrm{MoSi}_{2}$ compounds, ${ }^{[12,13]}$ metallic $\mathrm{Ti}^{[14]} \mathrm{Fe}-\mathrm{Ni}-\mathrm{Ti}-\mathrm{Al},{ }^{[15]}$ and $\mathrm{Fe}$ and $\mathrm{Ni}^{[16]}$ have all been utilized as sintering aids to improve relative density and mechanical response because these sintering aids have lower melting point, better wettability, or better plastic deformation ability. From the results provided in these and other studies, an important question emerges. That is, are there other sintering aids, not previously considered, that can possibly lead to enhanced density and fracture toughness in $\mathrm{TiB}_{2}$ ceramics? To that effect, we propose that in fact a metallic glass is an ideal sintering aid for $\mathrm{TiB}_{2}$ and the basis for this suggestion can be rationalized by the following points:

1) Metallic glass powder exhibits viscous flow behavior prior to crystallization, as compared with its crystalline counterparts. ${ }^{[17-19]}$ This will greatly accelerate the densification process during sintering, thereby resulting in a crystallized bulk alloy with a high relative density; ${ }^{[19,20]}$

2) Sintered and crystallized bulk alloys obtained from a metallic glass sintering aid present high room-temperature strength and ductility. This is typically attributed to grain refinement (nanocrystalline or ultrafine grains) induced by controlling nucleation and growth, ${ }^{[21]}$ an equiaxed microstructure, ${ }^{[22,23]}$ controlling crystallization kinetics ${ }^{[24]}$ and accelerating densification ${ }^{[20]}$ relative to bulk alloys that contain nanocrystalline or prealloyed powders as sintering aid;

3) Sintered and crystallized bulk alloys obtained from a metallic glass sintering aid reportedly exhibit excellent high-temperature mechanical properties. Moreover, controlled additions of $\mathrm{Ti}$ and $\mathrm{Al}$ into the sintering aid can prevent formation of undesirable brittle secondary borides, ${ }^{[25]}$ such as $\mathrm{MB}, \mathrm{M}_{2} \mathrm{~B}$, and $\mathrm{M}_{23} \mathrm{~B}_{6}$.

In view of the above argument, in this work, $\mathrm{Ti}_{60.8} \mathrm{Al}_{25} \mathrm{Nb}_{10} \mathrm{~V}_{3} \mathrm{Mo}_{1} \mathrm{~B}_{0.2}$ (at \%) metallic glass powder was first introduced as sintering aid to toughen $\mathrm{TiB}_{2}$-based ceramic composites fabricated by spark plasma sintering. $\mathrm{Ti}_{60.8} \mathrm{Al}_{25} \mathrm{Nb}_{10} \mathrm{~V}_{3} \mathrm{Mo}_{1} \mathrm{~B}_{0.2}$ high-temperature alloy composition was selected due to its excellent high-temperature mechanical properties. ${ }^{[26]}$ The fabricated $\mathrm{TiB}_{2}$-based ceramic composites have high relative density and fracture toughness, superior to those of $\mathrm{TiB}_{2}$-based ceramic composites containing metallic, compound and ceramic sintering aids. ${ }^{[1-15]}$ The work described here provides a new insight into the fabrication of highperformance ceramic composites for structural applications.

\section{Experimental Section}

\subsection{Sample Preparation}

The as-received titanium (-300 mesh, 99.7\%), aluminum (-300 mesh, $>99.7 \%)$, niobium (-325 mesh, 99.95\%), vanadium ( -300 mesh, 99.9\%), molybdenum ( -300 mesh, $99.95 \%)$, boron ( -325 mesh, $99.9 \%$ ), and titanium diboride
(3-5 $\mu \mathrm{m}, 99.9 \%$ ) powders were obtained from Zhongnuo New Materials Co., Ltd., Beijing, China. These elemental powders were initially mixed for $24 \mathrm{~h}$ with a stoichiometry of $\mathrm{Ti}_{60.8} \mathrm{Al}_{25} \mathrm{Nb}_{10} \mathrm{~V}_{3} \mathrm{Mo}_{1} \mathrm{~B}_{0.2}$ (at\%) in a blending machine. Mechanical alloying of the homogeneously mixed elemental powders was performed at a rotation rate of $248 \mathrm{rpm}$ under a purified argon gas atmosphere $(99.99 \%, 0.5 \mathrm{MPa})$ in a highenergy planetary ball mill (QM-2SP20-CL, apparatus factory of Nanjing University). Stainless steel vials and balls were utilized as the milling media with a ball-to-powder mass ratio of $7: 1$. The milling process was interrupted regularly every $10 \mathrm{~h}$ for cooling the milled powders to room temperature. Meanwhile, approximately $3 \mathrm{~g}$ of the as-milled powders were taken out from the mill containers every $10 \mathrm{~h}$ for various characterizations until achieving maximum content of glassy phase in the as-milled powder after $70 \mathrm{~h}$ milling. Subsequently, composite powders were prepared by mixing of $95 \mathrm{wt} \%$ as-received $\mathrm{TiB}_{2}$ ceramic powder and $5 \mathrm{wt} \% 70$ h-milled $\mathrm{Ti}_{60.8} \mathrm{Al}_{25} \mathrm{Nb}_{10} \mathrm{~V}_{3} \mathrm{Mo}_{1} \mathrm{~B}_{0.2}$ alloy powder, and were blended homogeneously for $12 \mathrm{~h}$ at $100 \mathrm{rpm}$ in the ball-miller. To avoid introducing oxygen impurity, all manipulation was performed under an argon atmosphere via vacuum glove-box.

Bulk Ti-based alloy and $\mathrm{TiB}_{2}$-based ceramic composites were fabricated, respectively, from the $70 \mathrm{~h}$-milled $\mathrm{Ti}_{60.8} \mathrm{Al}_{25} \mathrm{Nb}_{10} \mathrm{~V}_{3} \mathrm{Mo}_{1} \mathrm{~B}_{0.2}$ alloy powder and the aforementioned mixed composite powders by SPS (Dr. Sinter825, Sumitomo CoalMining Co. Ltd., Japan) in a cylindrical graphite die with an inside diameter of $20 \mathrm{~mm}$ as well as a protective layer of tantalum foil with a thickness of $30 \mu \mathrm{m}$. The sintering temperatures were selected as 1200,1300 , 1400 , and $1500{ }^{\circ} \mathrm{C}$ with a heating rate of $100^{\circ} \mathrm{Cmin}^{-1}$. The rationale used for the selection of these sintering temperatures is to obtain $\mathrm{TiAl}$ phase transformed from $\mathrm{Ti}_{60.8} \mathrm{Al}_{25} \mathrm{Nb}_{10} \mathrm{~V}_{3} \mathrm{Mo}_{1} \mathrm{~B}_{0.2}$ alloy powder sintering aid as predicted by the binary aluminum-titanium phase diagram. ${ }^{[27]}$ The temperatures were examined by infrared thermometer with a distance of $3 \mathrm{~mm}$ from the edge of powders in the present study. All SPS experiments were conducted at a constant pressure of $30 \mathrm{MPa}$. The pressure was not released until completed soaking for $5 \mathrm{~min}$ at the target sintering temperature under an argon atmosphere, and the specimens were cooled down to room temperature. In addition, instantaneous values of sintering parameters, such as temperature, punch displacement, and time, were recorded every $2 \mathrm{~s}$ by the attached software. The densification rate of the mixed composite powders was determined by calculating the derivative of punch displacement versus time.

\subsection{Phase Composition and Microstructure}

The evolution of structure as a function of milling time of the as-milled $\mathrm{Ti}_{60.8} \mathrm{Al}_{25} \mathrm{Nb}_{10} \mathrm{~V}_{3} \mathrm{Mo}_{1} \mathrm{~B}_{0.2}$ powers was confirmed by X-ray diffraction (XRD, D8 Advance, Bruker Co., Saarbrücken, Germany) with $\mathrm{Cu} \mathrm{K} \alpha$ radiation. The thermal stability was measured by differential scanning calorimetry 

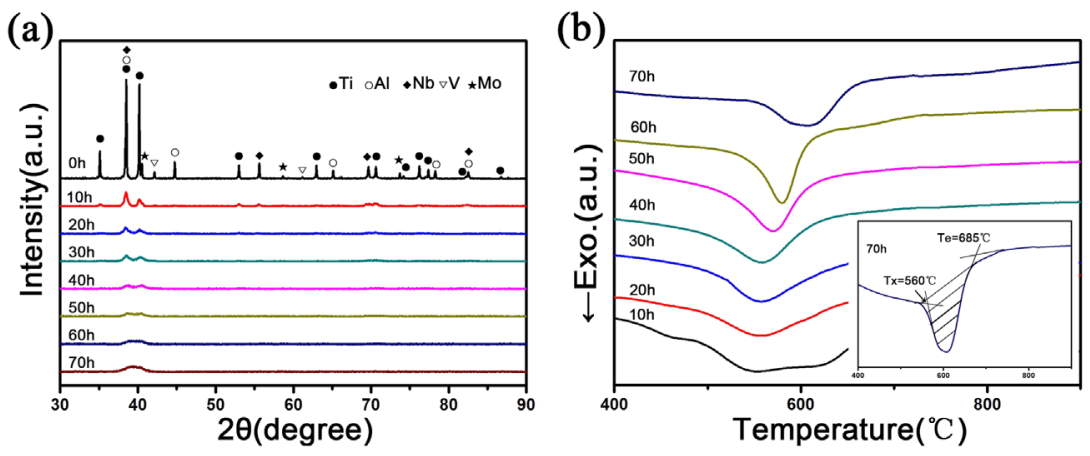

Fig. 1. XRD patterns (a) and DSC curves (b) of the milled $T i_{60.8} A l_{25} N b_{10} V_{3} M o_{1} B_{0.2}$ alloy powders after different milling times.

(DSC, Netzsch STA 409C) under a high-purity argon atmosphere at a heating rate of $20^{\circ} \mathrm{Cmin}^{-1}$. Transmission electron microscope (TEM; FEI, Eindhoven, The Netherlands) was used for microstructural observation of the $70 \mathrm{~h}$-milled $\mathrm{Ti}_{60.8} \mathrm{Al}_{25} \mathrm{Nb}_{10} \mathrm{~V}_{3} \mathrm{Mo}_{1} \mathrm{~B}_{0.2}$ alloy powder. The phase composition and microstructure of the fabricated bulk Ti-based alloy and $\mathrm{TiB}_{2}$-based ceramic composites were evaluated by XRD and high-resolution scanning electron microscopy (SEM, Nova Nano 430, FEI, Hillsboro, OR, USA) couple with energy dispersive spectroscopy (EDS).

\subsection{Mechanical Properties}

In order to study the mechanical behavior of the fabricated bulk Ti-based alloy under compression, cylindrical specimens of $3 \mathrm{~mm}$ in diameter and $6 \mathrm{~mm}$ in length were tested in a universal testing machine (MTS testing system) under quasi static loading at a strain rate of $5 \times 10^{-4} \mathrm{~s}^{-1}$, and a small strain gauge was used to calibrate and measure the strain during loading. Based on Archimedes principle, the density of the $\mathrm{TiB}_{2}$-based ceramic composite was measured using water. Its theoretical density was calculated to be $4.526 \mathrm{~g} \mathrm{~cm}^{-3}$ according to the rule of mixtures. The hardness (HV10) was evaluated using a Vickers hardness tester (430SVA, Wilson Wolpert Co. Ltd., Shanghai, China) with a load of $10 \mathrm{kgf}$ for $20 \mathrm{~s}$. The fracture toughness $\left(K_{\mathrm{IC}}\right)$ was calculated based on the
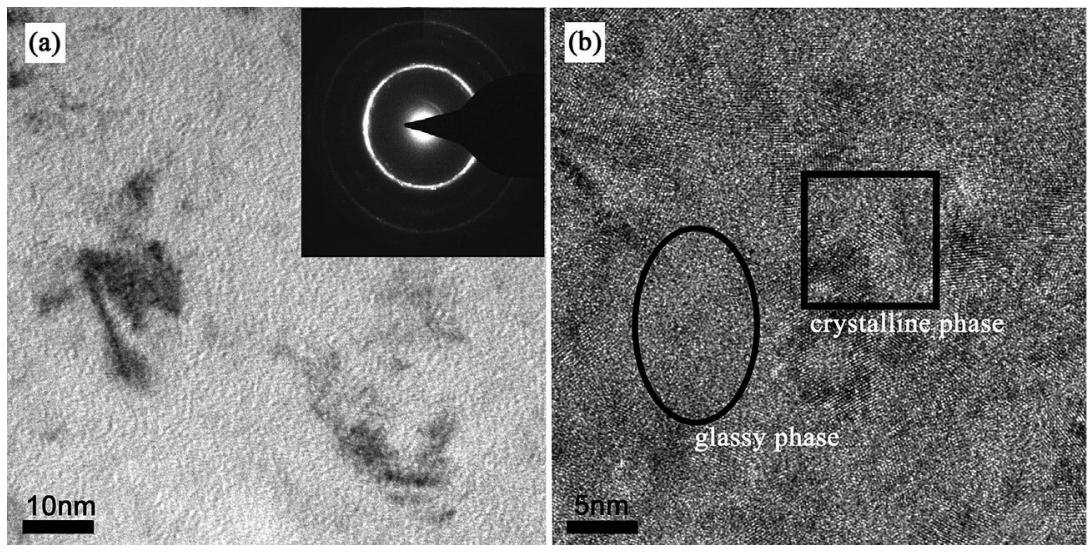

Fig. 2. (a) TEM micrograph and corresponding selected area diffraction pattern for the 70 h-milled $\mathrm{Ti}_{60.8} \mathrm{Al}_{25} \mathrm{Nb}_{10} \mathrm{~V}_{3} \mathrm{Mo}_{1} B_{0.2}$ alloy powder. (b) High-resolution TEM image of the 70 h-milled $\mathrm{Ti}_{60.8} \mathrm{Al}_{25} \mathrm{Nb}_{10} \mathrm{~V}_{3}$ $\mathrm{Mo}_{1} \mathrm{~B}_{0.2}$ alloy powder. radial crack length produced by the Vickers (HV10) indentation according to Anstis' formula. ${ }^{[28]}$ The reported values are the average of the data obtained from five indentation tests. The elastic properties of the $\mathrm{TiB}_{2}$-based ceramic composite were determined using a non-destructive test, i.e., the pulse-echo overlap ultrasonic technique using an ultrasonic detector. The Anstis' formula used to evaluate $K_{\text {IC }}$ is as follows: ${ }^{[28]}$

$$
K_{\mathrm{IC}}=16 \cdot\left(\frac{E}{H}\right)^{1 / 2} \cdot \frac{P}{C^{3 / 2}}
$$

where $E$ is the elastic modulus (GPa); $H$ is the Vickers hardness $(\mathrm{GPa}) ; P$ is the indentation load $(\mathrm{kgN})$; and $C$ is the total crack length $(\mu \mathrm{m})$ from each corner of the indent to the tip of the corresponding crack.

\section{Results and Discussion}

Figure 1 shows XRD patterns and DSC curves of the milled $\mathrm{Ti}_{60.8} \mathrm{Al}_{25} \mathrm{Nb}_{10} \mathrm{~V}_{3} \mathrm{Mo}_{1} \mathrm{~B}_{0.2}$ powders after different milling times. The starting mixture of elemental powders reveals diffraction patterns of $\mathrm{Ti}, \mathrm{Al}, \mathrm{Nb}, \mathrm{V}$, and Mo. After $10 \mathrm{~h}$ milling, the major peaks associated with the starting elemental powders decrease significantly. With increased milling time, both peak broadening and a gradual decrease in intensity of peaks can be observed due to reduction in grain size, increase in lattice distortion and decrease in crystallinity. The obvious appearance of diffuse diffraction implies formation of a glassy phase. After $70 \mathrm{~h}$ milling, the $\mathrm{Ti}_{60.8} \mathrm{Al}_{25} \mathrm{Nb}_{10} \mathrm{~V}_{3} \mathrm{Mo}_{1} \mathrm{~B}_{0.2}$ alloy powder has completely transformed into glassy phase. It has an onset crystallization temperature $\left(T_{x}\right)$ of $560^{\circ} \mathrm{C}$; crystallization event ends at $685^{\circ} \mathrm{C}$, called $T_{e}$. Its heat release of crystallization, or activation energy for the viscous flow obtained by integrating the area under the peak in DSC trace (Figure $1 \mathrm{~b}$ ), is $25.2 \mathrm{~J} \mathrm{~g}^{-1}$ at a heating rates of $20^{\circ} \mathrm{C} \mathrm{min}^{-1}$. The obtained heat release of crystallization here is comparable to other mechanically alloyed Tibased metallic glass powders. ${ }^{[29,30]}$

Further TEM analysis was employed to confirm the exactly existence of glassy phase in the 70-milled $\mathrm{Ti}_{60.8} \mathrm{Al}_{25} \mathrm{Nb}_{10} \mathrm{~V}_{3} \mathrm{Mo}_{1} \mathrm{~B}_{0.2}$ alloy powder (Figure 2). The corresponding selected area diffraction pattern in Figure 2a clearly shows a diffuse halo and bright diffraction rings. High-resolution TEM images confirm that this is indeed a glassy phase (Figure 2b). Meanwhile, there still exist some remained $\mathrm{Ti}_{3} \mathrm{Al}$ nanocrystalline phases (Figure 2b) surrounded by the glassy matrix, also as seen by the dark regions in Figure 2a. Considering that viscous flow behavior prior to crystallization 


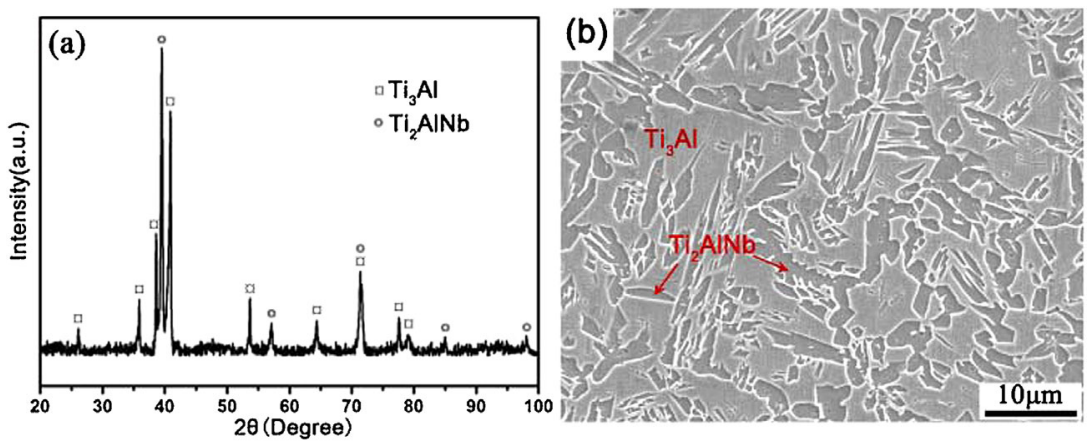

Fig. 3. XRD pattern (a) and SEM image (b) of the sintered and crystallized $T_{60.8} A l_{25} N b_{10} V_{3} M o_{1} B_{0.2}$ bulk alloy by heating to $1200^{\circ} \mathrm{C}$ at $100^{\circ} \mathrm{C} \mathrm{min}^{-1}$ and holding for $5 \mathrm{~min}$.

for metallic glass powder can greatly accelerate the densification process during sintering, thereby resulting in a high relative density for a crystallized bulk alloy, ${ }^{[19,20]}$ these results suggest that the $\mathrm{Ti}_{60.8} \mathrm{Al}_{25} \mathrm{Nb}_{10} \mathrm{~V}_{3} \mathrm{Mo}_{1} \mathrm{~B}_{0.2}$ metallic glass powder would enhance the sintering mechanism by facilitating viscous flow and thereby leading to a high sintering density sintering aid.

Figure 3 shows XRD pattern and SEM image of the sintered and crystallized $\mathrm{Ti}_{60.8} \mathrm{Al}_{25} \mathrm{Nb}_{10} \mathrm{~V}_{3} \mathrm{Mo}_{1} \mathrm{~B}_{0.2}$ bulk alloy which was accomplished by heat to $1200^{\circ} \mathrm{C}$ at $100^{\circ} \mathrm{C} \mathrm{min}^{-1}$ and holding for $5 \mathrm{~min}$. Because the sintering temperature exceeds $T_{x}\left(560^{\circ} \mathrm{C}\right)$ of the $70 \mathrm{~h}$-milled $\mathrm{Ti}_{60.8} \mathrm{Al}_{25} \mathrm{Nb}_{10} \mathrm{~V}_{3} \mathrm{Mo}_{1} \mathrm{~B}_{0.2}$ metallic glass powder, the sintered and crystallized bulk alloy is principally composed of crystallized $\mathrm{Ti}_{3} \mathrm{Al}$ and $\mathrm{Ti}_{2} \mathrm{AlNb}$ phases (Figure 3a). SEM analysis indicates that the two-phase regions are characterized by scale of several micrometers and contains fine interleaving bands of $\mathrm{Ti}_{2} \mathrm{AlNb}$ or lamellae in the $\mathrm{Ti}_{3} \mathrm{Al}$ matrix (Figure $3 \mathrm{~b}$ ). The room temperature compression testing results reveals that the sintered and crystallized bulk alloy has a yield strength of $1475 \mathrm{MPa}$, ultimate fracture strength of $2414 \mathrm{MPa}$, and fracture strain of $24.8 \%$, respectively. Notably, these values are higher than the corresponding ones for many solidified titanium alloys containing a nanostructured matrix with in situ precipitated ductile dendrites. ${ }^{[21-23]}$ In addition, the Vickers hardness of the sintered and crystallized bulk alloy is $4.38 \pm 0.5 \mathrm{GPa}$.

Figure 4 shows the densification curve corresponding to the $\mathrm{TiB}_{2}$-based ceramic composite powder containing $5 \mathrm{wt} \%$ sintering aid of the $70 \mathrm{~h}$-milled $\mathrm{Ti}_{60.8} \mathrm{Al}_{25} \mathrm{Nb}_{10} \mathrm{~V}_{3}$ $\mathrm{Mo}_{1} \mathrm{~B}_{0.2}$ metallic glass powder using heating rate of $100{ }^{\circ} \mathrm{C} \mathrm{min}^{-1}$. The results in this figure suggest that there are three shrinkage stages, or three instantaneous maximum values of shrinkage rate corresponding to the temperature ranges: $585-695,695-730$, and $>730^{\circ} \mathrm{C}$, respectively. It is interesting to note that compared with a single instantaneous maximum value of shrinkage rate below $730^{\circ} \mathrm{C}$ in the case of sintering $\mathrm{TiB}_{2}$-based ceramic composite powder containing $5 \mathrm{wt} \%(\mathrm{Fe}-\mathrm{Ni}-\mathrm{Ti}-\mathrm{Al})$ crystalline sintering aid ${ }^{[15]}$ the material containing $5 \mathrm{wt} \%$ metallic glass sintering aid exhibits two instantaneous maximum values of shrinkage rate. The first shrinkage stage occurs within the temperature range of $585-695^{\circ} \mathrm{C}$, approximately corresponding to the onset $\left(560^{\circ} \mathrm{C}\right)$ and completion $\left(685^{\circ} \mathrm{C}\right)$ crystallization temperatures of the $70 \mathrm{~h}$-milled $\mathrm{Ti}_{60.8} \mathrm{Al}_{25} \mathrm{Nb}_{10} \mathrm{~V}_{3} \mathrm{Mo}_{1} \mathrm{~B}_{0.2}$ metallic glass powder in Figure $1 \mathrm{~b}$, and has a sigmoidal curve and a significant shrinkage displacement above $1 \mathrm{~mm}$. This particular sigmoidal shrinkage behavior is ascribed to the viscous flow of the metallic glass sintering aid, consistent with results reported for the sintering of monolithic $\mathrm{Ti}_{40.6} \mathrm{Zr}_{9.4} \mathrm{Cu}_{37.5-}$ $\mathrm{Ni}_{9.4} \mathrm{Al}_{3.1}$ metallic glass powder during SPS. ${ }^{[20]}$ Also, the fact that the first instantaneous maximum value of shrinkage rate is similar to that of monolithic $\mathrm{Ti}_{40.6} \mathrm{Zr}_{9.4} \mathrm{Cu}_{37.5} \mathrm{Ni}_{9.4} \mathrm{Al}_{3.1}$ metallic glass powder, ${ }^{[20]}$ provides support to the suggestion that this behavior is related to the viscous flow of pure metallic glass powder. Moreover, this shrinkage behavior will accelerate densification relative to the crystalline counterpart powder, ${ }^{[20]}$ thereby leading to a higher density. The second

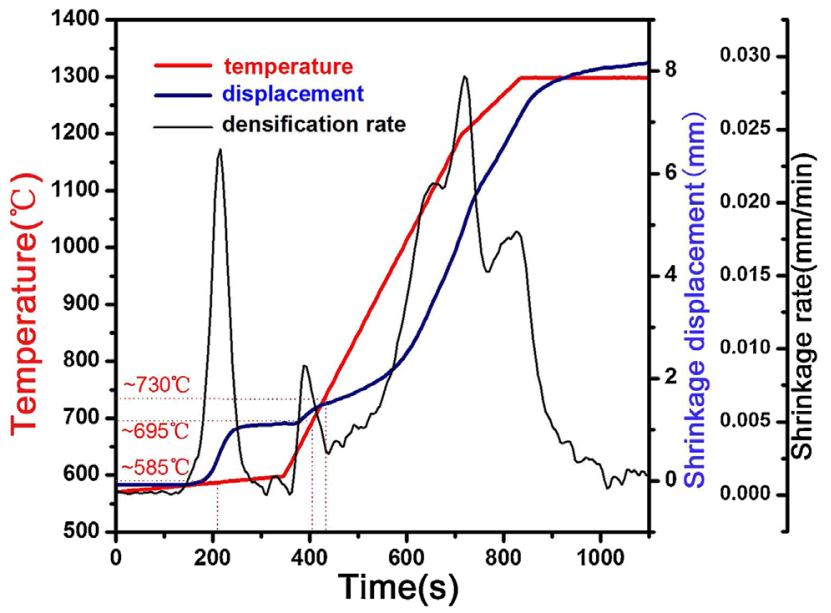

Fig. 4. Densification curve of the $\mathrm{TiB}_{2}$-based ceramic composite powder containing $5 \mathrm{wt}$ $\%$ sintering aid of the $70 \mathrm{~h}$-milled $\mathrm{Ti}_{60.8} \mathrm{Al}_{25} \mathrm{Nb}_{10} \mathrm{~V}_{3} \mathrm{Mo}_{1} \mathrm{~B}_{0.2}$ metallic glass powder by a heating rate of $100^{\circ} \mathrm{C} \mathrm{min}^{-1}$.

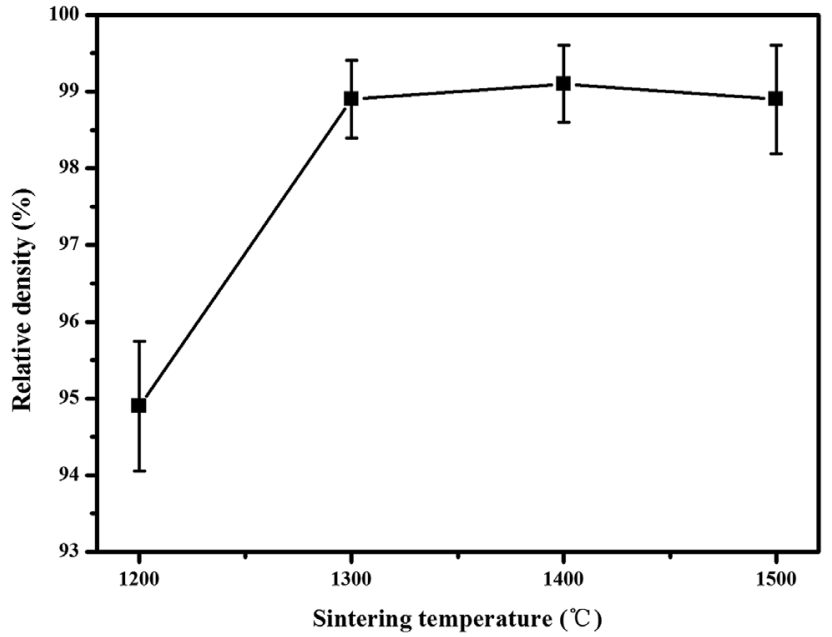

Fig. 5. Influence of sintering temperature on relative density of the $\mathrm{TiB}_{2}$-based ceramic composites containing $5 w \%$ metallic glass sintering aid. 
Table 1. Relative density, microhardness, elastic modulus, and fracture toughness of the TiB $B_{2}$-based ceramic composites containing 5 wt $\%$ MG sintering aid.

\begin{tabular}{|c|c|c|c|c|c|c|}
\hline Material compositions & $\begin{array}{l}\text { Processing details } \\
{\left[{ }^{\circ} \mathrm{C}, \mathrm{min}, \mathrm{MPa}\right]}\end{array}$ & $\begin{array}{c}\text { Relative } \\
\text { density [\%] }\end{array}$ & $\begin{array}{c}\text { Crack } \\
\text { lengths } \\
{[\mu \mathrm{m}]}\end{array}$ & $\begin{array}{c}\text { Elastic } \\
\text { modulus } \\
\text { [GPa] }\end{array}$ & $\begin{array}{c}\text { Vickers } \\
\text { hardness [GPa] }\end{array}$ & $\begin{array}{l}\text { Fracture toughness } \\
\qquad\left[\mathrm{MPa} \mathrm{m}^{1 / 2}\right]\end{array}$ \\
\hline Monolithic $\mathrm{TiB}_{2}{ }^{[32]}$ & SPS, $1500,10,40$ & 96.1 & - & 397.9 & 17.4 & 5.4 \\
\hline $\mathrm{TiB}_{2}-5 \mathrm{wt} \% \mathrm{CrB}_{2}^{[11]}$ & $\mathrm{HP}, 1750,60,35$ & 94.8 & - & - & 23.7 & 4.3 \\
\hline $\mathrm{TiB}_{2}-5 \mathrm{wt} \% \mathrm{MoSi}_{2}{ }^{[13]}$ & $\mathrm{HP}, 1700,60,30$ & 98.8 & _- & _- & 26.2 & 5.0 \\
\hline $\mathrm{TiB}_{2}-2.5 \mathrm{wt} \% \mathrm{Ti}^{[14]}$ & SPS, $1650,5,50$ & 99.1 & - & - & 26.8 & 5.9 \\
\hline $\mathrm{TiB}_{2}-5 \mathrm{wt} \% \mathrm{Fe}-\mathrm{Ni}-\mathrm{Ti}-\mathrm{Al}{ }^{[15]}$ & SPS, $1500,5,30$ & 97.6 & 115.8 & 471.2 & 19.7 & 6.2 \\
\hline $\begin{array}{l}\mathrm{TiB}_{2}-5 \mathrm{wt} \% \text { TiAlNbVMoB } \\
\mathrm{MG} \text {, present work }\end{array}$ & SPS, $1300,5,30$ & $98.9 \pm 0.51$ & $86 \pm 1.63$ & $431 \pm 8.82$ & $21 \pm 1.43$ & 9.0 \\
\hline $\begin{array}{l}\mathrm{TiB}_{2}-5 \mathrm{wt} \% \text { TiAlNbVMoB } \\
\mathrm{MG} \text {, present work }\end{array}$ & SPS, $1400,5,30$ & $99.1 \pm 0.51$ & $83 \pm 1.08$ & $454 \pm 7.93$ & $20 \pm 0.95$ & 9.9 \\
\hline $\begin{array}{l}\mathrm{TiB}_{2}-5 \mathrm{wt} \% \text { TiAlNbVMoB } \\
\text { MG, present work }\end{array}$ & SPS, $1500,5,30$ & $98.9 \pm 0.71$ & $116 \pm 0.96$ & $478 \pm 8.37$ & $21 \pm 0.91$ & 6.0 \\
\hline
\end{tabular}

Crack lengths from each corner of the indent to the tip of the corresponding crack in the $\mathrm{TiB}_{2}$-based ceramic composites is measured by SEM and used to calculate fracture toughness. For comparison, related parameters of monolithic $\mathrm{TiB}_{2}$ ceramics as well as $\mathrm{TiB}_{2}$-based ceramic composites with various sintering aids are also presented.

HP, Hot pressing; SPS, Spark plasma sintering; MG, Metallic glass.

shrinkage stage, or instantaneous maximum value of shrinkage rate between 695 and $730^{\circ}$, occurs at a temperature that is slightly higher than that corresponding to the completion crystallization temperature $\left(685^{\circ} \mathrm{C}\right)$ of the metallic glass powder (Figure 1b), and is attributed to presence of a substantial amount of quasi-amorphous layers at the grain boundaries ${ }^{[19]}$ in crystallized nanocrystalline powder transformed from the metallic glass sintering aid. When the sintering temperature exceed $730^{\circ} \mathrm{C}$, the third shrinkage stage is attributed to the crystallized $\mathrm{Ti}_{60.8} \mathrm{Al}_{25} \mathrm{Nb}_{10} \mathrm{~V}_{3} \mathrm{Mo}_{1} \mathrm{~B}_{0.2}$ sintering aid with grew ultrafine grains. The different peaks, or instantaneous maximum value of shrinkage rates may be related to formation of $\mathrm{Ti}(\mathrm{O}, \mathrm{C}, \mathrm{N})$ solid solution and $\mathrm{Al}_{2} \mathrm{O}_{3}$ phases and the decomposition of the $\mathrm{Ti}_{3} \mathrm{Al}$ phase at 1200 and $1300{ }^{\circ} \mathrm{C}$ in the crystallized $\mathrm{Ti}_{60.8} \mathrm{Al}_{25} \mathrm{Nb}_{10} \mathrm{~V}_{3} \mathrm{Mo}_{1} \mathrm{~B}_{0.2}$ sintering aid, as discussed about phase identification in Figure 6 and 7.

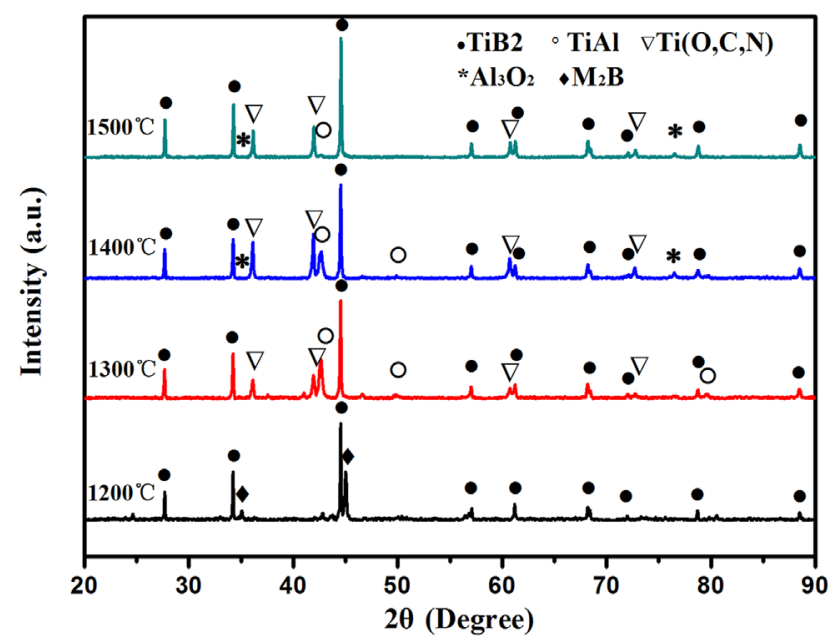

Fig. 6. XRD patterns for the $\mathrm{TiB}_{2}$-based ceramic composites containing $5 w t \%$ metallic glass sintering aid fabricated at different sintering temperatures.
The changes in relative density of the $\mathrm{TiB}_{2}$-based ceramic composites depend strongly on sintering temperature, as shown in Figure 5. A rapid increase in the relative density is observed in the range of $1200-1300^{\circ} \mathrm{C}$. When the sintering temperature reaches $1300^{\circ} \mathrm{C}$, the relative density remains relatively unchanged and approaches $99.0 \%$ of theoretical; further increases in the sintering temperature do not appear to improve this value. It is apparent from the results summarized in Table 1 that this value of relative density is significantly higher than that of $\mathrm{TiB}_{2}$-based ceramic composites with the same amount of sintering aid of $\mathrm{CrB}_{2}$ ceramic, ${ }^{[11]}$ $\mathrm{MoSi}_{2}$ compound, ${ }^{[12,13]}$ and $\mathrm{Fe}-\mathrm{Ni}-\mathrm{Ti}-\mathrm{Al} .{ }^{[15]}$

Figure 6 shows XRD patterns for the $\mathrm{TiB}_{2}$-based ceramic composites containing $5 \mathrm{wt} \%$ metallic glass sintering aid fabricated using different sintering temperatures. At a sintering temperature of $1200^{\circ} \mathrm{C}$, the fabricated $\mathrm{TiB}_{2}$-based ceramic composite consists of two primary constituent phases: $\mathrm{TiB}_{2}$ and $\mathrm{M}_{2} \mathrm{~B}(\mathrm{M}=\mathrm{Nb}, \mathrm{V}$, and $\mathrm{Mo})$. Because of the small volume fraction of the $\mathrm{Ti}_{3} \mathrm{Al}$ it fails to appear in the XRD spectra. When the sintering temperature increases to $1300^{\circ} \mathrm{C}$, the main constituent phases include: $\mathrm{TiB}_{2}, \mathrm{TiAl}$, and $\mathrm{Ti}(\mathrm{O}, \mathrm{C}$, $\mathrm{N}$ ) phases, accompanied with the disappearance of formed $\mathrm{M}_{2} \mathrm{~B}$ phase. When the temperature is increased to $1400^{\circ} \mathrm{C}$, the content of TiAl decreases slightly and the content of $\operatorname{Ti}(\mathrm{O}, \mathrm{C}$, $\mathrm{N}$ ) increases largely, accompanied with the appearance of small amount of the $\mathrm{Al}_{2} \mathrm{O}_{3}$ phase. With further increases in temperature to $1500{ }^{\circ} \mathrm{C}$, the TiAl phase cannot be detected. According to the binary aluminum-titanium phase diagram, ${ }^{[27]}$ the $\mathrm{Ti}_{3} \mathrm{Al}$ phase decomposes into the $\mathrm{TiAl}$ and $\alpha-\mathrm{Ti}$ phases, and the TiAl and $\beta$-Ti phases when the temperature exceeds 1200 and $1300^{\circ} \mathrm{C}$, respectively. Thus, the formation of the $\operatorname{Ti}(\mathrm{O}, \mathrm{C}, \mathrm{N})$ solid solution phase with interstitial atoms $(\mathrm{O}$, $\mathrm{C}, \mathrm{N})$ at $1300^{\circ} \mathrm{C}$ is attributed to the reactions between the impurities $(\mathrm{O}, \mathrm{C}, \mathrm{N})$ on the starting $\mathrm{TiB}_{2}$ powders, surface and the decomposed $\alpha-\mathrm{Ti}^{\left[{ }^{[2]}\right.}$ The increased $\mathrm{Ti}(\mathrm{O}, \mathrm{C}, \mathrm{N})$ content 

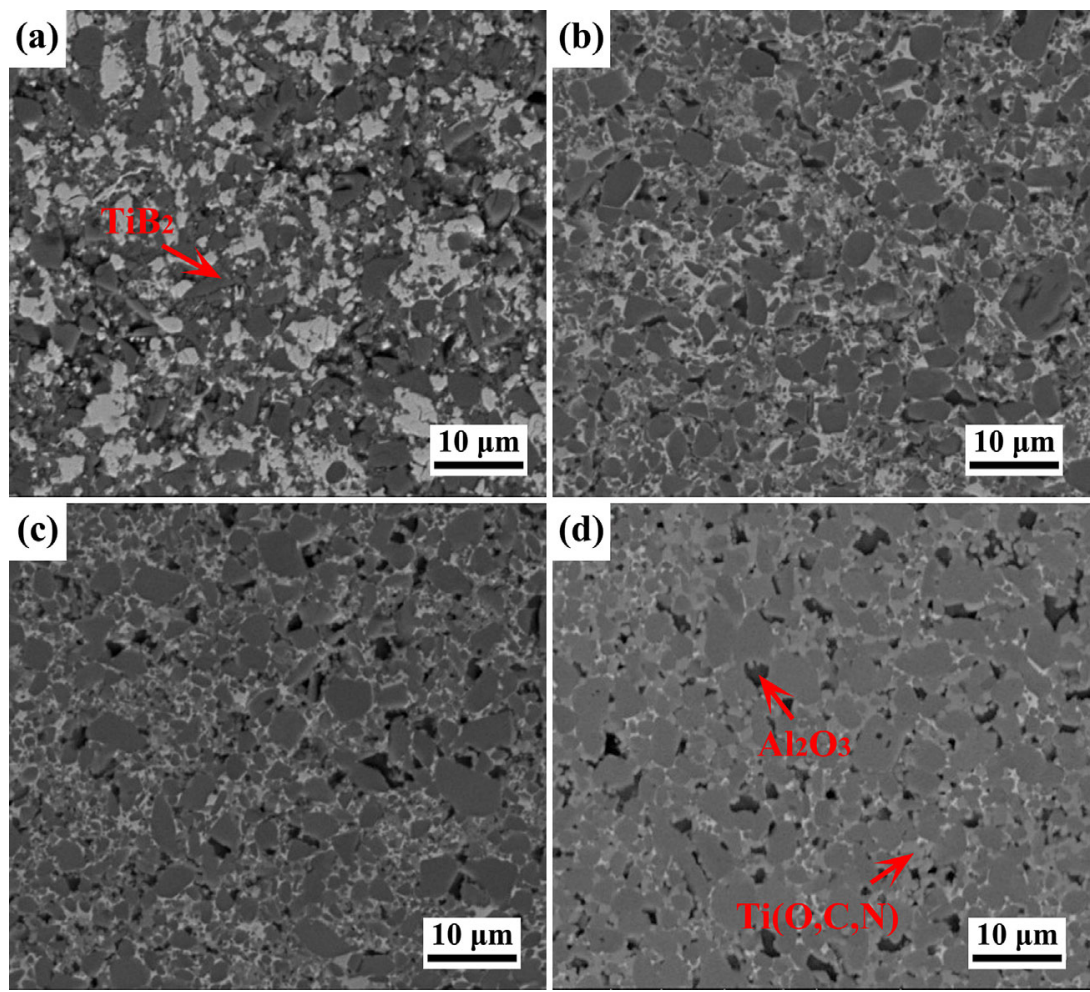

Fig. 7. Back-scattered SEM images of the TiB - -based ceramic composites containing $5 w t \%$ metallic glass sintering aid fabricated at different sintering temperatures: (a) $1200^{\circ} \mathrm{C},\left(\right.$ b) $1300^{\circ} \mathrm{C},(c) 1400^{\circ} \mathrm{C}$, and (d) $1500^{\circ} \mathrm{C}$.

with the increased sintering temperature may result from more $\mathrm{O}$ impurity uptake from surrounding environment. Moreover, the disappearance of formed $\mathrm{M}_{2} \mathrm{~B}(\mathrm{M}=\mathrm{Nb}, \mathrm{V}$, and Mo) phase at $1300^{\circ} \mathrm{C}$ may be due to the decomposed $\alpha$-Ti. ${ }^{[25]}$ The constituted elements $\mathrm{M}(=\mathrm{Nb}, \mathrm{V}$, and $\mathrm{Mo})$ may react with the decomposed $\alpha$-Ti and thus stabilize and form $\beta$-Ti phase, having an positive influence on the mechanical properties of the $\mathrm{TiB}_{2}$-based ceramic composites as presented in Figure 8 and Table 1. Likewise, the formation of a small quantity $\mathrm{Al}_{2} \mathrm{O}_{3}$ at $1400^{\circ} \mathrm{C}$ can be ascribed to the reaction between the decomposed Al with introduced minor oxygen existing in the powders during the sintering process. This suggestion is consistent with the fact that the $\mathrm{Ti}_{3} \mathrm{Al}$ aid used in sintering the $\mathrm{TiB}_{2}$ ceramic powder decomposed at $1350^{\circ} \mathrm{C}$ into $\mathrm{Ti}$ and $\mathrm{Al}$ and decomposed $\mathrm{Al}$ reacted with $\mathrm{O}$ to form $\mathrm{Al}_{2} \mathrm{O}_{3}$ particles. ${ }^{[31]}$ In addition, the disappearance of the TiAl phase at $1500^{\circ} \mathrm{C}$ may simply be attributable to its small volume fraction and partial decomposition. ${ }^{[27]}$

Figure 7 shows back-scattered SEM images of the $\mathrm{TiB}_{2}$-based ceramic composites containing $5 \mathrm{wt} \%$ metallic glass sintering aid fabricated at different sintering temperatures. The gray black region corresponds to the $\mathrm{TiB}_{2}$ ceramic phase; a small part of gray white phase is confirmed to be $\operatorname{Ti}(\mathrm{O}, \mathrm{C}, \mathrm{N})$ solid solution, and the content of $\operatorname{Ti}(\mathrm{O}, \mathrm{C}, \mathrm{N})$ increased significantly with increasing sintering temperature. Moreover, the bright white phase corresponds to the TiAl intermetallic compounds, and with increasing sintering temperature, its proportion decreases gradually. In addition, the $\mathrm{Al}_{2} \mathrm{O}_{3}$ phase is associated with dark spots (see arrows), and it is evenly distributed between the ceramic particles. The average chemical compositions of the $\operatorname{Ti}(\mathrm{O}, \mathrm{C}, \mathrm{N})$ solid solution, TiAl intermetallic compound, and $\mathrm{Al}_{2} \mathrm{O}_{3}$ phases determined by EDS in the $\mathrm{TiB}_{2}$-based ceramic composites fabricated at $1500{ }^{\circ} \mathrm{C}$ are $\mathrm{Ti}_{59.8} \mathrm{O}_{36.9} \mathrm{C}_{3.3}, \mathrm{Ti}_{50.5} \mathrm{Al}_{39.0} \mathrm{Fe}_{2.6} \mathrm{O}_{4.2} \mathrm{C}_{3.7}$, and $\mathrm{Al}_{23.6} \mathrm{O}_{69.7} \mathrm{Ti}_{6.7}$, respectively. This proves that the correctness of phase identification in Figure 6 and 7.

Figure 8 presents the influence of the sintering temperature on grain size, microhardness, elastic modulus, and fracture toughness of the $\mathrm{TiB}_{2}$-based ceramic composites containing $5 \mathrm{wt} \%$ metallic glass sintering aid. Generally, the hardness of
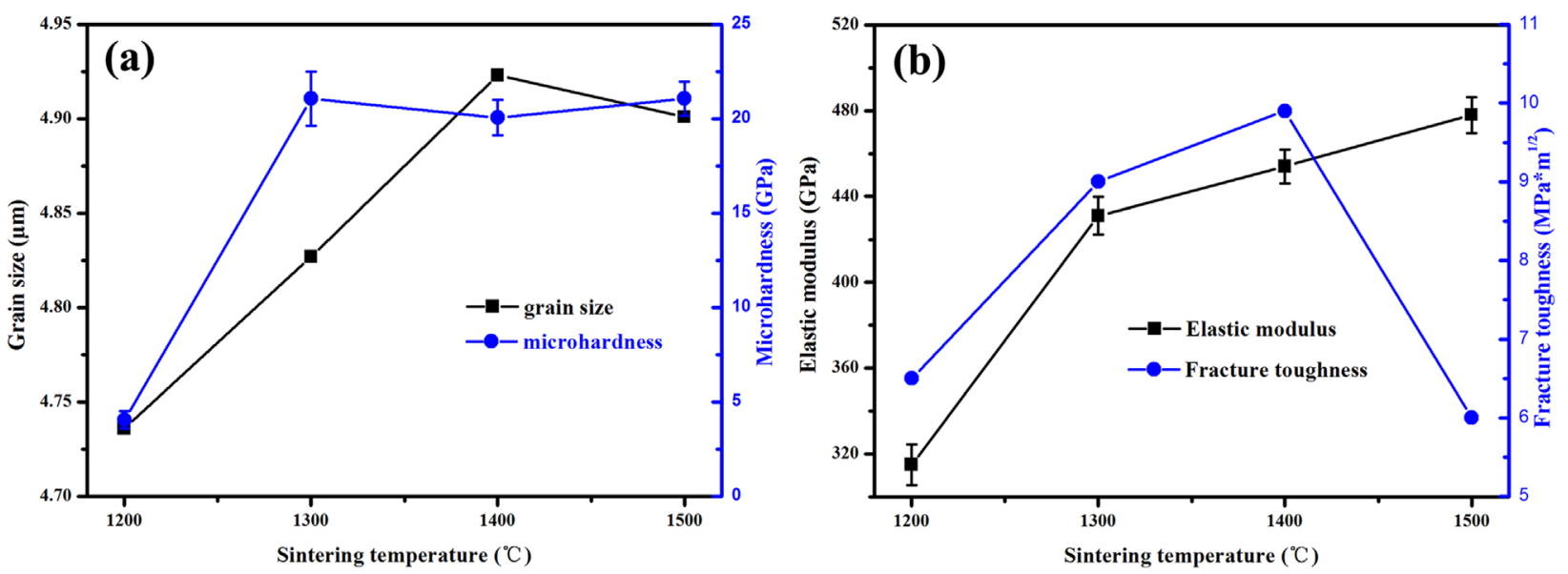

Fig. 8. Influence of sintering temperature on grain size, microhardness, elastic modulus, and fracture toughness of the TiB ${ }_{2}$-based ceramic composites containing 5 wt $\%$ metallic glass sintering aid. 


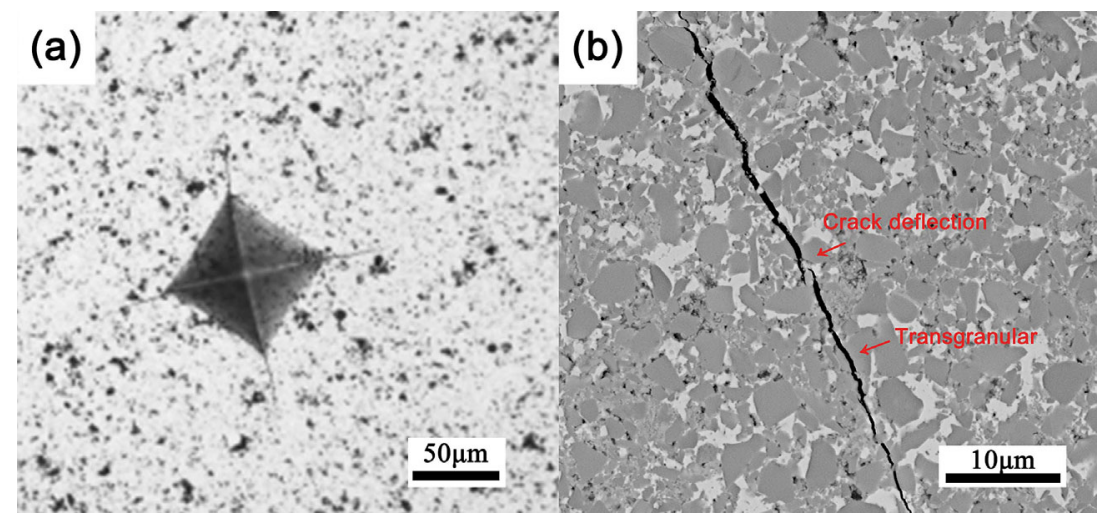

Fig. 9. (a) Vickers hardness indentation topography and (b) crack propagation path in the TiB ${ }_{2}$-based ceramic composites containing $5 \mathrm{wt} \%$ metallic glass sintering aid fabricated at $1500^{\circ} \mathrm{C}$.

\section{Conclusion}

$\mathrm{TiB}_{2}$-based ceramic composites containing $5 \mathrm{wt} \%$ sintering aid of $\mathrm{Ti}_{60.8} \mathrm{Al}_{25} \mathrm{Nb}_{10} \mathrm{~V}_{3} \mathrm{Mo}_{1} \mathrm{~B}_{0.2}$ (at $\%$ ) metallic glass powder were fabricated by spark plasma sintering. Densification process analysis indicates that the composite powders have a sigmoidal viscous flow densification behavior before the crystallization ends for the metallic glass sintering aid. The $\mathrm{TiB}_{2}$-based ceramic composites fabricated at $1400^{\circ} \mathrm{C}$ have high relative density of $99.1 \%$ and high fracture toughness of $9.9 \mathrm{MPa} \mathrm{m}^{1 / 2}$. The excellent combination between relative density and fracture toughness is attributed to the accelerated densification effect induced by the bulk materials reveals a strong dependence on grain size and relative density. The grain size of the $\mathrm{TiB}_{2}$ phase in the fabricated $\mathrm{TiB}_{2}$-based ceramic composites revealed in Figure $8 \mathrm{a}$ is below $4.9 \mu \mathrm{m}$, suggesting an absence of grain growth as compared with the as-received $\mathrm{TiB}_{2}$ powder. The hardness trend is similar to that of relative density and it remains relatively constant when sintering temperature exceeds $1300^{\circ} \mathrm{C}$. Therefore, it can be deduced that the hardness is primarily affected by the relative density. As seen in Figure 8b, the elastic modulus increases with the increased sintering temperature. This may be principally attributed to the elimination of pores. However, the fracture toughness increases first with the increased sintering temperature, has maximums at the sintering temperatures of 1300 and $1400{ }^{\circ} \mathrm{C}$, and decreases with the further increased sintering temperature to $1500^{\circ} \mathrm{C}$. Its change is consistent with the content change in TiAl phase (Figure 6) in the fabricated $\mathrm{TiB}_{2}$-based ceramic composites. This indicates that the increased fracture toughness may be due to the enhancement in bond strength between the $\mathrm{TiB}_{2}$ phase and the crystallized TiAl phase from sintering aid. As expected, the $\mathrm{TiB}_{2}$-based ceramic composites fabricated between 1300 and $1400^{\circ} \mathrm{C}$ exhibit an excellent combination of microhardness and fracture toughness (Table 1). The measured fracture toughness is superior to those for $\mathrm{TiB}_{2}$-based ceramic composites with the same content sintering aid of $\mathrm{CrB}_{2}$ ceramic, ${ }^{[11]} 4.3 \mathrm{MPa} \mathrm{m}^{1 / 2}, \mathrm{MoSi}_{2}$ compound, ${ }^{[13]} 5.0 \mathrm{MPa} \mathrm{m}^{1 / 2}$, metallic $\mathrm{Ti}_{1}^{[14]} 6.2 \mathrm{MPa} \mathrm{m}^{1 / 2}$, and $\mathrm{Fe}-\mathrm{Ni}-\mathrm{Ti}-\mathrm{Al}{ }^{[15]}$ 6.2 $\mathrm{MPa} \mathrm{m}^{1 / 2}$. The fracture toughness can be attributed to the outstanding mechanical response of the constituent phase TiAl transformed from the $\mathrm{Ti}_{60.8} \mathrm{Al}_{25} \mathrm{Nb}_{10} \mathrm{~V}_{3} \mathrm{Mo}_{1} \mathrm{~B}_{0.2}$ metallic glass sintering aid. ${ }^{[26]}$

Through observing the indentation topography after the Vickers hardness measurement in Figure 9a, cracks propagate from the four corners of the crease, respectively. It can be observed in Figure $9 \mathrm{~b}$ that fracture occurs primarily via a transgranular mechanism and that some crack deflection is also evident. The transgranular fracture mode is a result of the high density as well as stronger bonding between the $\mathrm{TiB}_{2}$ and sintering aid. metallic glass sintering aid and the excellent mechanical property of the constituted TiAl phase transformed from the metallic glass sintering aid. The novel idea provides a new insight into fabricating high-performance ceramic composites in structural application.

Article first published online: $x x x x$ Manuscript Revised: August 11, 2016 Manuscript Received: April 28, 2016

[1] E. Bilgi, H. E. Camurlu, B. Akgun, Y. Topkaya, N. Sevinc, Mater. Res. Bull. 2008, 43, 873.

[2] W. Ji, J. Y. Zhang, W. M. Wang, H. Wang, F. Zhang, Y. C. Wang, Z. Y. Fu, J. Eur. Ceram. Soc. 2015, 35, 879.

[3] A. Jain, R. Pankajavalli, S. Anthonysamy, K. Ananthasivan, R. Babu, V. Ganesan, G. S. Gupta, J. Alloys Compd. 2010, 491, 747.

[4] G. B. Raju, B. Basu, J. Am. Ceram. Soc. 2007, 90, 3415.

[5] W. M. Wang, Z. Y. Fu, H. Wang, R. Z. Yuan, J. Eur. Ceram. Soc. 2002, 22, 1045.

[6] F. C. Wang, Z. H. Zhang, J. Luo, C. C. Huang, S. K. Lee, Compos. Sci. Technol. 2009, 69, 2682.

[7] P. Li, W. C. Zhou, J. K. Zhu, F. Luo, D. M. Zhu, Scr. Mater. 2009, 60, 760.

[8] K. Biswas, B. Basu, A. K. Suri, K. Chattopadhyay, Scr. Mater. 2006, 54, 1363.

[9] W. Chen, U. A. Tamburini, J. E. Garay, J. R. Groza, Z. A. Munir, Mater. Sci. Eng. A. 2005, 394, 132.

[10] Z. A. Munir, U. A. Tamburini, M. Ohyanagi, J. Mater. Sci. 2006, 41, 763.

[11] T. S. R. Ch. Murthy, J. K. Sonber, C. Subramanian, R. K. Fotedar, M. R. Gonal, A. K. Suri, Int. J. Refract. Met. H 2009, 27, 976.

[12] T. S. R. Ch. Murthy, B. Basu, R. Balasubramaniam, A. K. Suri, C. Subramanian, R. K. Fotedar, J. Am. Ceram. Soc. 2006, 89, 131.

[13] A. Mukhopadhyay, G. B. Raju, B. Basu, A. K. Suri, J. Eur. Ceram. Soc. 2009, 29, 505. 
[14] Z. H. Zhang, X. B. Shen, F. C. Wang, S. K. Lee, Q. B. Fan, M. S. Cao, Scr. Mater. 2012, 66, 167.

[15] C. Yang, H. Guo, D. G. Mo, S. G. Qu, X. Q. Li, W. W. Zhang, L. C. Zhang, Materials 2014, 7, 7105.

[16] D. A. Hoke, M. A. Meyers, J. Am. Ceram. Soc. 1995, 78, 275.

[17] G. Wang, J. Shen, J. F. Sun, Y. J. Huang, J. Zou, Z. P. Lu, Z. H. Stachurski, B. D. Zhou, J. NonCryst. Solids 2005, 351, 209.

[18] S. Scudino, B. Bartusch, J. Eckert, J. Phys. Conf. Ser. 2009, 144, 012097.

[19] V. V. Dabhade, T. R. R. Mohan, P. Ramakrishnan, Mater. Res. Bull. 2007, 42, 1262.

[20] L. H. Liu, C. Yang, Y. G. Yao, F. Wang, W. W. Zhang, Y. Long, Y. Y. Li, Intermetallics 2015, 66, 1.

[21] L. H. Liu, C. Yang, L. M. Kang, Y. Long, Z. Y. Xiao, P. J. Li, L. C. Zhang, Mater. Sci. Eng. A 2016, 650, 171.

[22] L. H. Liu, C. Yang, F. Wang, S. G. Qu, X. Q. Li, W. W. Zhang, Y. Y. Li, L. C. Zhang, Mater. Des. 2015, 79, 1.
[23] C. Yang, L. H. Liu, Q. R. Cheng, D. D. You, Y. Y. Li, Mater. Sci. Eng. A 2013, 580, 397.

[24] C. Yang, L. H. Liu, Y. G. Yao, Y. H. Li, Y. Y. Li, J. Alloys Compd. 2014, 586, 542.

[25] M. G. Barandika, J. M. Sánchez, T. Rojo, R. Cortés, F. Castro, Scr. Mater. 1998, 39, 1395.

[26] R. U. Vaidya, Z. Jin, C. Cady, G. T. Gray III, D. P. Butt, Scr. Mater. 1999, 41, 569.

[27] J. C. Schuster, M. Palm, J. Phase Equilib. Diff. 2006, 27, 255.

[28] G. R. Anstis, P. Chantikul, B. R. Lawn, J. Am. Ceram. Soc. 1981, 64, 533.

[29] Y. Y. Li, C. Yang, W. P. Chen, X. Q. Li, J. Mater. Res. 2008, 23, 745 .

[30] L. C. Zhang, Z. Q. Shen, J. Xu, Mater. Sci. Eng. A 2005, 394, 204.

[31] J. M. Sánchez, I. Azcona, F. Castro, J. Mater. Sci. 2000, 35, 9.

[32] A. Mukhopadhyay, T. Venkateswaran, B. Basu, Scr. Mater. 2013, 69, 159. 